\title{
The effect of breast size and bra type on comfort for UK female police officers wearing body armour
}

Chris Malbon ${ }^{1}$, Dr Clare Knock ${ }^{1}$, Dr Richard Critchley ${ }^{1}$, Prof Debra J Carr².

1. Centre for Defence Engineering, Cranfield University, Defence Academy of the United Kingdom, Shrivenham, Wiltshire, SN6 8LA

2. Previously 1, now Defence and Security Accelerator, Porton Down, Salisbury SP4 0JQ

\begin{abstract}
Within the Police service of England and Wales the wearing of ballistic and stab resistant body armour is common, with most police forces mandating its usage when away from the police station. Of all the serving police officers in England and Wales 29.1\% are female (Hargreaves et al., 2017). A survey was developed and then distributed by the Police Federation of England and Wales to all servicing police officers up to the rank of Inspector. The survey returned 2633 responses after cleaning of the data. From the responses it was seen that the predominant bra type worn is underwired (71\%) and the predominant UK bra size is 34B (9\%). It was also determined that the predominant areas where the body armour either rubbed or caused discomfort were the left and right anterior mammary regions and the posterior lateral sacral region. By understanding the distribution of bra size, type of bra worn and areas of discomfort or rubbing it helps further understand the issues faced by female police officers and how body armour design could be improved.
\end{abstract}

\section{Keywords}

UK bra size, Sports bra, Underwired bra, Activity

\subsection{Introduction}

Within England and Wales there are 43 separate police forces (39 England, 4 Wales) with a total of 123,142 serving police officers, of which $29.1 \%(35,834)$ are female (Hargreaves et al., 2017). All these officers will have been issued with a body armour suitable for their role. Each individual police force is responsible for the supply of body armour to their officers, therefore the style, manufacturer and materials used may be different between police forces. Typically the body armour issued will provide resistance to low velocity ballistic and stab threats (Lewis et al., 2017). These factors can affect the form and fit of the armour to the wearer.

The wearing of body armour is mandated in most police forces within England and Wales when officers are away from the police station, typically being worn for between 8 to 12 
hours without being removed. This includes wearing in police vehicles, while patrolling or dealing with incidents.

In designing body armour for ballistic and stab resistance for any wearer, a designer has to take into account conflicting requirements, including but not limited to; coverage, protection levels, flexibility, comfort and fitting to body form.

The design of body armour intended for female wearers has improved over recent years, however, these improvements are limited and generally involve the folding, stitching, tapering or layering of the materials to form breast-like shapes. The use of anthropometric measurements for the design of clothing and PPE for both male and female forms has been reviewed (Carr et al., 2012). This review of literature at that time (2012) highlighted that the use of anthropometric measurements would become crucial in the correct sizing of clothing and PPE. A much earlier study analysed clothing size measurements that had been collected from 1217 female US military personnel in 1977 (Salusso-Deonier et al., 1985). This study showed that the measurement systems used when the data was collected did not take into account overall body proportions, resulting in poorly fitted clothing. A study of 139 female American soldiers was conducted which investigated the fit of armour on females and the effects on performance (Mithchell et al., 2010). They were able to show that the correct fitting of armour to the person was crucial to minimising effects on human performance, which relates to the optimisation of user centred design of armour.

More recent studies have investigated the use of $3 \mathrm{D}$ scanning techniques and $3 \mathrm{D}$ weaving to create better formed and shaped armours (Abtew et al., 2018) (Abtew et al., 2017) (Cichocka et al., 2014) (Mahbub et al., 2014) (Boussu and Bruniaux, 2012). However, this research has not significantly influenced the design and development of female body armour since it was introduced into the UK in the late 1990s. Additionally, the range of sizes available is limited depending upon the number of sizes of body armour a manufacturer wishes to make and does not necessarily compare to standard UK bra sizing.

The certification testing of police body armour for both male and female officers in the UK is conducted in accordance with the 2017 Home Office Body Armour Standard (Payne et al., 2017). For armours designed for the female form, the standard stipulates the requirements for ballistic and stab testing using standardised female forms of two sizes. Whilst the use of these standardised female forms has improved the assurance in testing of body armour, it has not driven the development of the design and comfort of body armour. 
Activity and the effect this can have on the female breast, in terms of movement and discomfort, has been extensively studied in the literature. Several studies have investigated the effects of running on breast pain and how bra type, design and fit are all influencing factors on individual perceived comfort e.g. (Milligan et al., 2014) (Brown et al., 2014). These studies showed that the type of bra used influenced the level of perceived discomfort for the wearer. Research focused on the effects of larger breasts (UK D cup and above) during exercise has considered both support and the kinematics of running (White et al., 2015). Breast support was a factor in pain levels, with greater support reducing perceived pain. However, the level of support provided by the bra played no factor on the kinematics of running. Although this research did not consider the wearing of body armour, polices officers are routinely required to perform strenuous physical activities, including running and selfdefence techniques. As such the research is important when considering factors that may affect the comfort of female police officers when wearing armour.

A number of studies have been reported that looked at the effect of body armour and equipment carried by male police officers and its effect on mobility e.g. (Dempsey et al., 2013) (Lewinski et al., 2015). Two studies reported on similar work also included a female cohort (Filtness et al., 2014) (Ramstrand et al., 2016). All the studies reported that equipment and body armour affected the officer mobility, such as flexion and extension of the trunk, and as such affected the officer ability to perform task efficiently.

Therefore, the wearing of body armour affects perceived comfort and limits or reduces the ability to perform actions which may be amplified for female officers if the design of the armour is poor, or if the wrong style or size of bra is being used.

Although behind armour blunt trauma ${ }^{1}$ (BABT) is not the focus of this paper, it is important to discuss it briefly to provide an overall picture of the issues. The effects of BABT on the human body have been well reported in the literature (Carr et al., 2013). Most of the studies on BABT focused on a flat torso shape and mainly considered the effects of a nonperforating ballistic impact over the ribs or abdomen. There have been two preliminary studies on the effects of BABT over the spine looking at both soft and hard armour impacts (R.M. Jennings et al., 2018) (Rosalind M Jennings et al., 2018). This work showed that impacts over the spine resulted in different injury mechanism than had been seen on anterior torso impacts. There has been a limited study done on the effects of non-perforating ballistic

\footnotetext{
1 “....spectrum of non-penetrating injuries to the torso resulting from the impact of projectiles on personal armours." (Cannon, 2001)
} 
impacts on the female torso (Bir and Wilhelm, 2004). This study reviewed injuries sustained by four female police officers and compared them to injuries sustained by ten male officers. Of the four female case studies, only two were on the anterior of the torso, one over the heart and one defined as 'left chest'. The authors noted that this study was limited, and further data collection was needed to gain a further understanding of the differences between male and females. They did recommend that a separate criterion be developed for testing of female armour which considered the size and stature of the wearer. The low number of impacts directly over the breast limits the usefulness of the study for this work.

Due to the nature of the materials typically used in body armour (e.g. multiple layers of woven fabric, laminated materials, chain mail), they do not allow for a fit that easily conforms to the contours of the body. Other factors also complicate the design of female armours including the shape of the bust, the type of bra being worn under the body armour or the correct shaping of the armour to the female form. One of the main areas of concern with relation to armour design for females is the correct fit. Tilsley et al, demonstrated that a 10 $\mathrm{mm}$ airgap under the armour can increase the risk of a ballistic projectile perforating the armour when compared to an armour that is close fitting to the body (Tilsley et al., 2018). Air gaps can form above, between and below the breast depending on how the armour is designed which could potential result in a ballistic perforation. Understanding more about the factors that may affect the fit of female body are important in developing the design of armour in the future.

The profile of the female body is dependent on breast size, body shape and type of bra worn, which the design of the body armour has to conform to. The aim of this paper was to develop an insight of preliminary data of factors that may affect the comfort, fit and usage of body armour by UK female police officers by understanding

- the type of bra that is normally worn by a female police officer in combination with body armour

- the range of bra sizes worn by female police officers in England and Wales,

- which areas on the body are uncomfortable for female officers and

- other factors that may influence the comfort of the body armour.

\subsection{Method}

2.1 Survey development and delivery 
To deliver on the aims of this work a survey was developed to collate relevant information from female police officers in England and Wales (annex 1). The survey was designed to ensure anonymity of the participants to aid response rate. Bra size was determined by asking the respondent to declare their current UK bra size they routinely wear in combination with their body armour in inches and cup designation (Zheng et al., 2006) (Pechter, 1998) (International Organization for Standarization (ISO), 2017). In addition, the respondents were requested to define the type of bra they would normally wear under their body armour, such as underwired, sports bra, padded etc. Further details were added to the survey to provide a more comprehensive understanding of issues for female police officer when wearing body armour. These included:

- the number of years body armour has been worn for,

- role,

- comfort when wearing body armour and performing defined actions,

- where, if any, the body armour was uncomfortable and / or it rubbed

To identify areas of discomfort and / or rubbing of the body armour, an image was created showing the anterior, posterior and sides of a generic female torso. This enabled officers to identify any area they had discomfort, not just the breast area. Participants could select up to ten locations of discomfort on this image, which was the limit of the survey software used. Each point identified by the respondent was counted, therefore if a respondent clicked multiple times in one area each click counted for the analysis.

This image was sub divided into 14 distinct zones to aid in data analysis (Figure 1 and Table 1). These zones were selected to divide the anterior of the body into left and right areas at the shoulder and breast areas and were then carried around to the posterior of the body. 

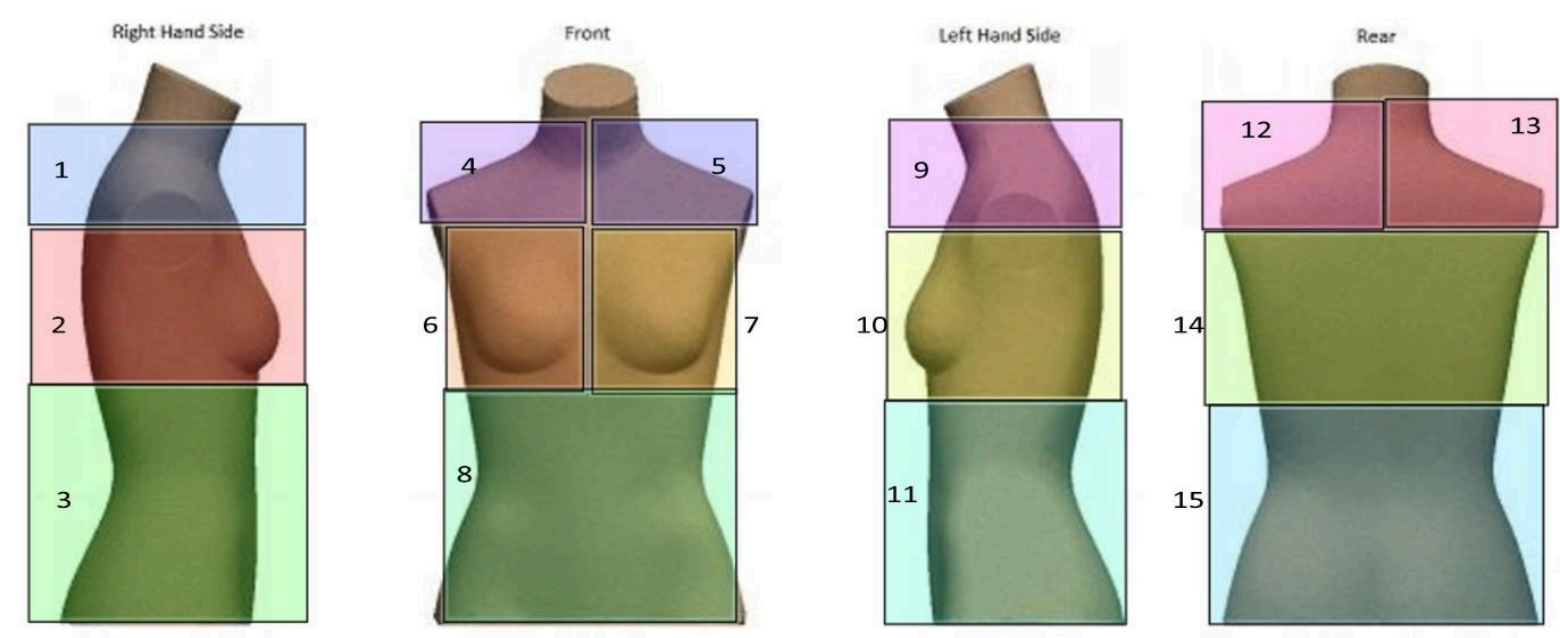

Figure 1 Torso image with zones and identifiers

\begin{tabular}{|c|c|c|c|}
\hline $\begin{array}{l}\text { Zone on } \\
\text { image }\end{array}$ & Descriptor & $\begin{array}{c}\text { Zone on } \\
\text { image }\end{array}$ & Descriptor \\
\hline 1 & Right shoulder region (deltoid) & 9 & $\begin{array}{l}\text { Left shoulder region } \\
\text { (deltoid) }\end{array}$ \\
\hline 2 & Right lateral mammary region & 10 & $\begin{array}{c}\text { Left lateral mammary } \\
\text { region }\end{array}$ \\
\hline 3 & Right loin / flank & 11 & Left loin / flank \\
\hline 4 & $\begin{array}{l}\text { Right anterior shoulder region } \\
\text { (deltoid) }\end{array}$ & 12 & $\begin{array}{l}\text { Left posterior shoulder } \\
\text { region }\end{array}$ \\
\hline 5 & $\begin{array}{l}\text { Left anterior shoulder region } \\
\text { (deltoid) }\end{array}$ & 13 & $\begin{array}{c}\text { Right posterior shoulder } \\
\text { region }\end{array}$ \\
\hline 6 & Right anterior mammary region & 14 & Posterior thoracic region \\
\hline 7 & Left anterior mammary region & 15 & $\begin{array}{c}\text { Posterior lumbar-sacral } \\
\text { region }\end{array}$ \\
\hline 8 & Abdominal region & & \\
\hline
\end{tabular}

Table 1 Descriptive terminology for body area zones

Ethical approval of the survey was obtained from Cranfield University Ethics committee (Reference: CURES/1609/2016).

The survey was prepared for on-line distribution using Qualtrics@ survey software ${ }^{2}$, which enabled the responses to questions to be coded for simpler data analysis. In addition, the use of Qualtrics@ enabled the survey to be distributed via a web link to increase the target population pool. Internal testing of the survey was conducted to ensure functionality prior to it being distributed. The survey was distributed by the Police Federation of England and Wales, which represents police officers up to and including the rank of inspector, to its

\footnotetext{
${ }^{2}$ www.qualtrics.com
} 
female members at the beginning of July 2016. The survey was kept open until October 2016 when the response rate had dropped to zero for the previous two weeks.

\subsection{Data cleaning}

After closing the survey there were 3213 responses, the data was downloaded from Qualtrics to Microsoft Excel to enable the data to be reviewed and filtered to remove or correct any inaccurate or incomplete data.

The following criteria were used to remove records:

- survey not completed $0.6 \%(n=19)$

- insufficient data submitted, for example entering bra size as 34 or just $D$ rather than 34D $17 \%(n=558)$

- where stated 'body armour not worn' $0.4 \%(n=4)$

Post cleaning of the survey data, 2633 responses remained which was a reduction of $18 \%$

For the category 'Role type', where a participant had selected 'other' and specified their own role designation, they were reviewed and grouped to standardised categories with the assistance of a serving police officer ${ }^{3}$. This was required due to the diverse nature of roles within the Police of England and Wales and resulted in a total of nine categories being used for 'role'; Routine patrol, Specially trained firearms officer, Specially trained public order officer, Traffic officer, Detective, Custody/offender management, Police Community support officer, Civilian staff, Other. Certain roles were collated together under the term 'other' as the number of respondents was two or less.

For the type of bra worn, where 'other' was specified these were reviewed to ensure that a significant style of bra was not prominent in this category. In addition, where a participant stated something similar to 'mainly underwired, occasional sports bra' it was re-classified as underwired in the response.

For the determination of areas of rubbing, any indications that fell outside of torso images were discounted from the survey to ensure the analysis of the response only counted valid indications.

\footnotetext{
${ }^{3}$ Chief Inspector with 25 years' service
} 
For the comfort while wearing body armour and performing actions, no additional cleaning of the data was required as these were fixed responses.

\subsection{Data analysis}

All data analysis was conducted using IBM® SPSS Statistics v24. Data was presented as frequency plots or tabulated as percentages of respondents to the question.

The full data set is available at DOI: $10.17862 /$ cranfield.rd.10059434

\subsection{Results}

The initial response to the survey was $8.9 \%(n=3213)$ of female police officers in England and Wales. Once the data cleaning, as described in section 2.2, had been completed, the number of responses remaining was $7.3 \%$ of female police officers in England and Wales ( $\mathrm{n}$ $=2633)$.

\subsection{Summary of respondents' answers}

The range of years that body armour had been worn for is shown in Figure 2. The largest group of respondents had worn armour for six to ten years (34.76\%). Overall $78.65 \%$ of respondents had been wearing body armour for more than five years. This demonstrated that the largest proportion of respondents were experienced of working in body armour having worn it for more than five years. The number of years that the respondent had worn body armour does not necessarily relate to the number of years' service or the age of the respondent. 


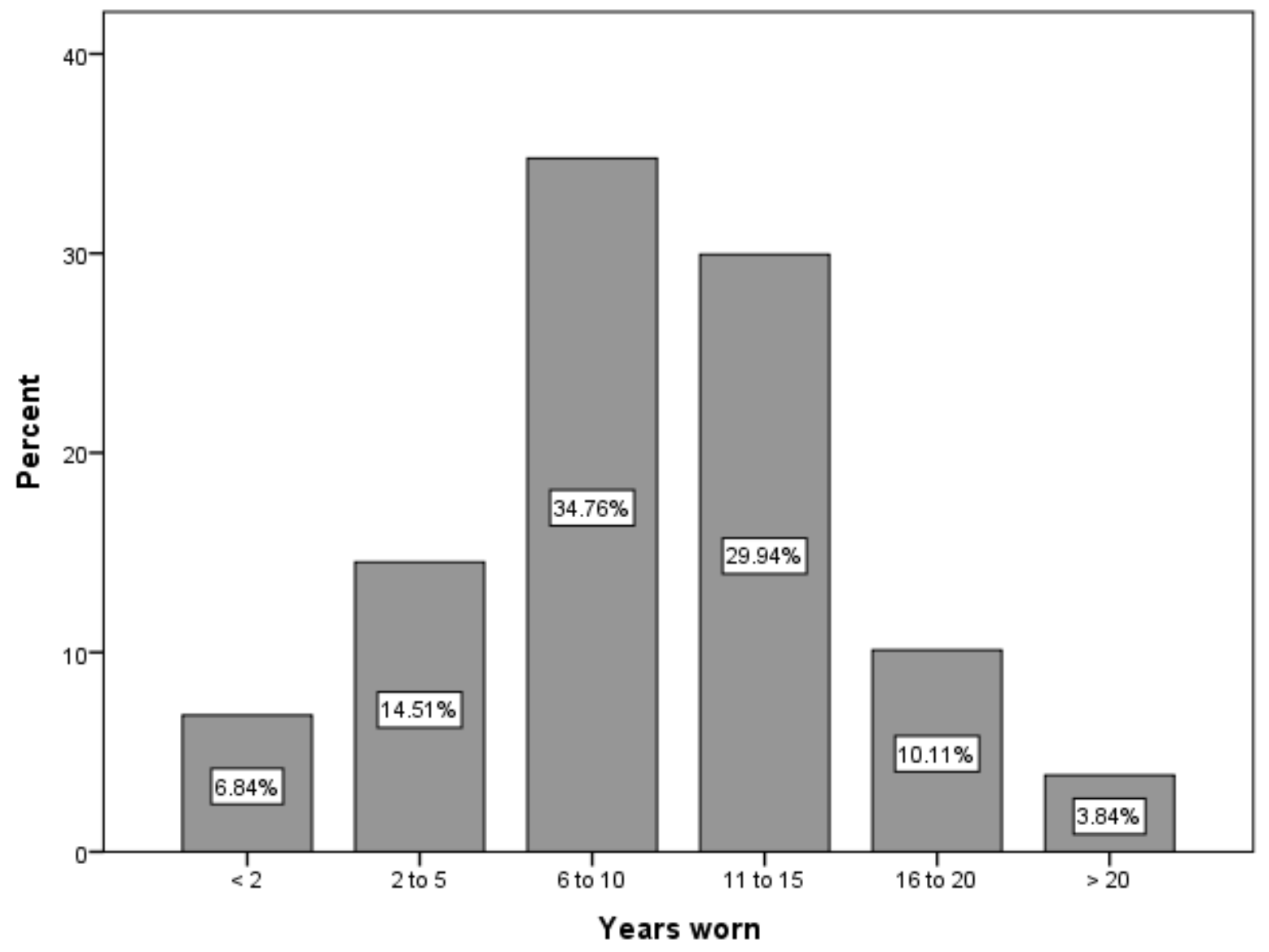

Figure 2 Years that body armour been worn for by percentage

The most common type of bra worn was underwired (70.83\%) with the second most common being sports bras (16.97\%) as shown in Figure 3. Very few officers did not wear a bra $(0.46 \%)$. 


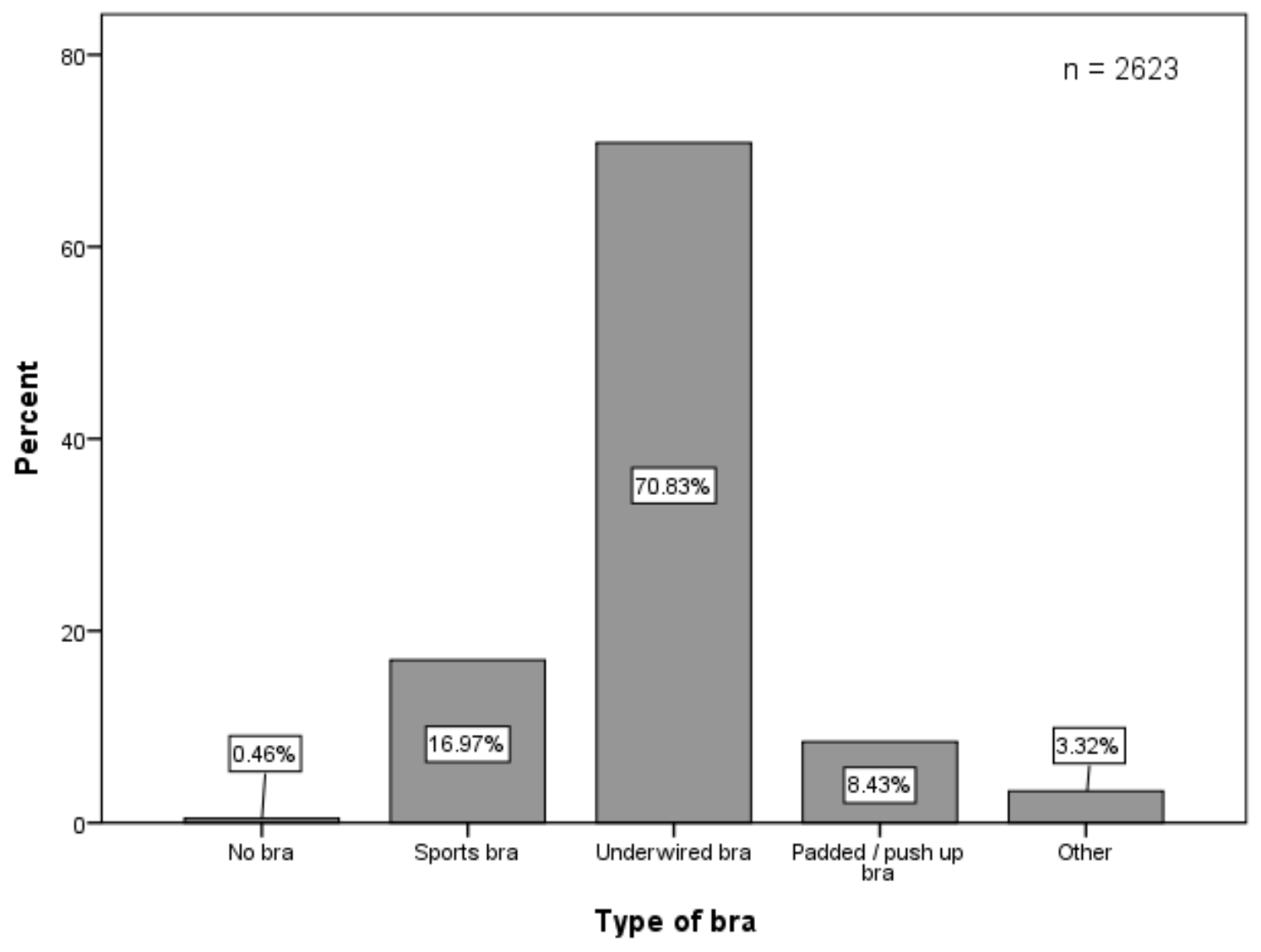

Figure 3 Type of bra normally worn under body armour

The distribution of bra sizes (i.e. the UK bra size the respondent is currently wearing) is shown in Figure 4. The most common UK bra size was 34B (9\%) followed closely by 36C and $34 \mathrm{C}(8 \%)$. The smallest bra size was $23 \mathrm{~B}$ and the largest bra size was $80 \mathrm{C}$, each with 1 respondent. The top 10 UK bra sizes worn by the respondents are shown in Table 2. 


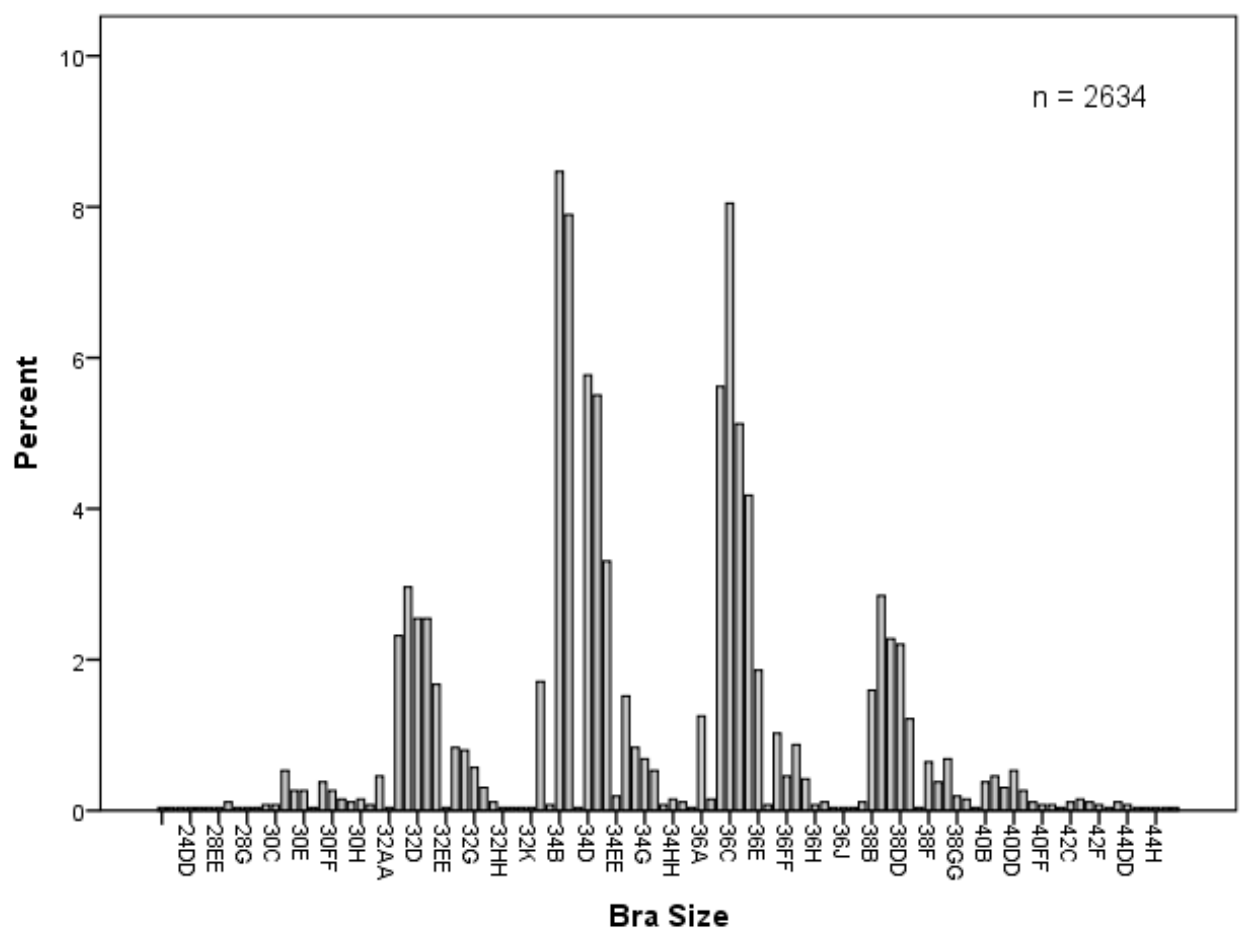

Figure 4 distribution of respondent specified UK bra size

\begin{tabular}{|l|c|c|}
\hline Bra size & Count & $\begin{array}{l}\text { \% of all } \\
\text { responses }\end{array}$ \\
\hline $34 B$ & 223 & 9 \\
\hline $36 C$ & 212 & 8 \\
\hline $34 C$ & 208 & 8 \\
\hline $34 D$ & 152 & 6 \\
\hline $36 B$ & 148 & 6 \\
\hline $34 D D$ & 145 & 6 \\
\hline $36 D$ & 135 & 5 \\
\hline $36 D D$ & 110 & 4 \\
\hline $32 C$ & 78 & 3 \\
\hline $38 C$ & 75 & 3 \\
\hline
\end{tabular}

Table 210 most common UK bra sizes as specified by respondent

The relationship between bra size and bra type for the top 10 bra sizes is shown in Table 3 . As chest size increases the ratio between wearing sports bra to underwired bra increases (32C $13: 68 \%, 38 \mathrm{C} 27: 65 \%$ ) as can be seen in Figure 5 


\begin{tabular}{|l|c|c|c|c|c|}
\hline \multirow{2}{*}{ Bra size $(\mathrm{n})$} & \multicolumn{5}{|c|}{ Bra type } \\
\cline { 2 - 6 } & None & Sports & Underwired & Padded/Push up & Other \\
\hline 32C (78) & $0 \%$ & $13 \%$ & $68 \%$ & $15 \%$ & $4 \%$ \\
\hline $34 \mathrm{~B}(220)$ & $1 \%$ & $14 \%$ & $64 \%$ & $17 \%$ & $4 \%$ \\
\hline $34 \mathrm{C}(207)$ & $0 \%$ & $12 \%$ & $73 \%$ & $12 \%$ & $3 \%$ \\
\hline $34 \mathrm{D}(151)$ & $0 \%$ & $15 \%$ & $76 \%$ & $8 \%$ & $1 \%$ \\
\hline $34 \mathrm{DD}(145)$ & $1 \%$ & $12 \%$ & $79 \%$ & $6 \%$ & $1 \%$ \\
\hline 36B (148) & $1 \%$ & $16 \%$ & $69 \%$ & $10 \%$ & $4 \%$ \\
\hline 36C (212) & $0 \%$ & $19 \%$ & $67 \%$ & $8 \%$ & $5 \%$ \\
\hline 36D (135) & $0 \%$ & $18 \%$ & $75 \%$ & $4 \%$ & $4 \%$ \\
\hline 36DD (110) & $0 \%$ & $25 \%$ & $68 \%$ & $5 \%$ & $3 \%$ \\
\hline 38C (74) & $0 \%$ & $27 \%$ & $65 \%$ & $3 \%$ & $5 \%$ \\
\hline
\end{tabular}

Table 3 Bra type worn in relation to most common bra size declared

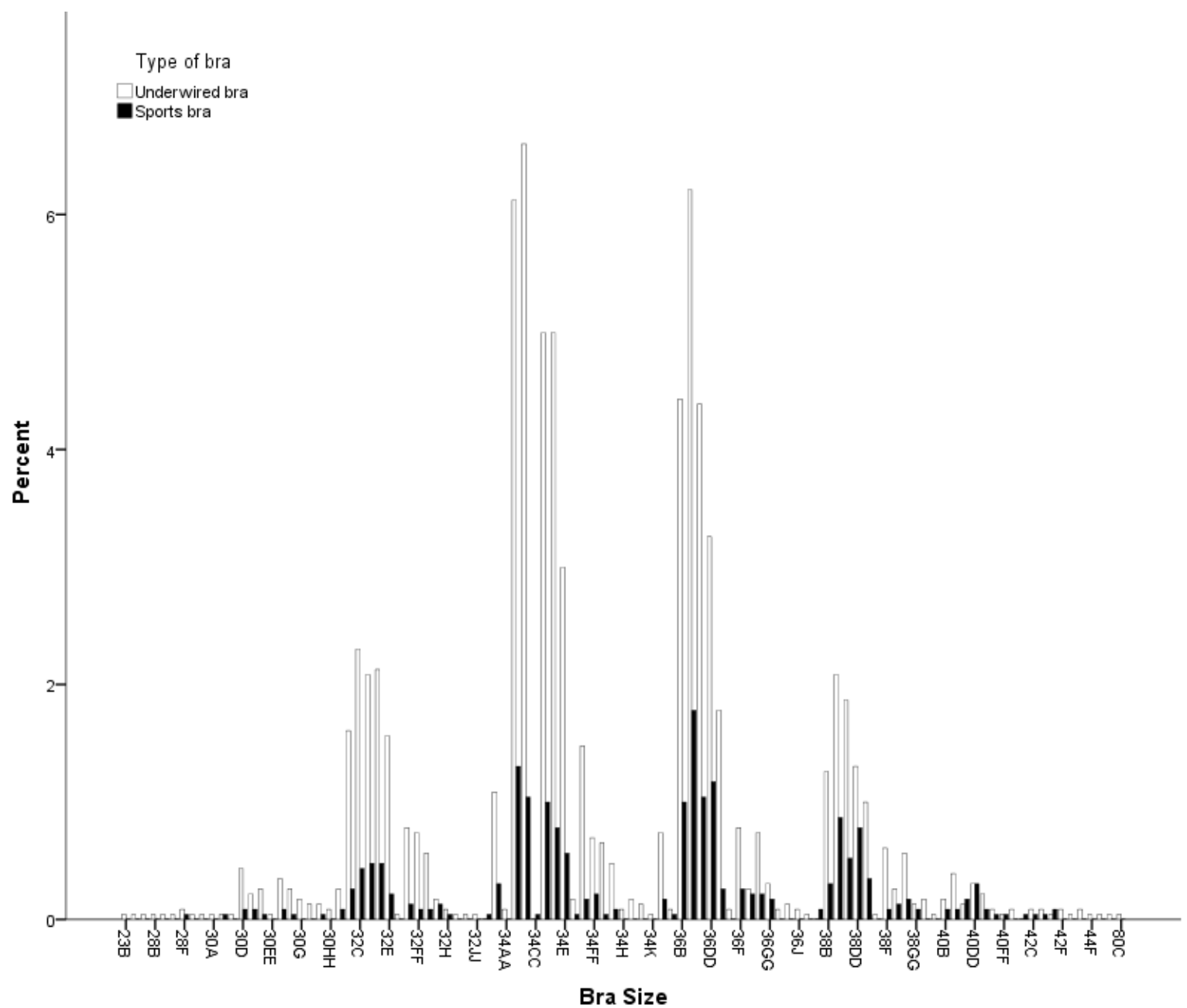

Figure 5 Comparison of underwired and sports bra to declared UK bra size 
The primary role of the respondents was reviewed in relation to the type of bra worn (Table 4). In all roles the main bra type worn is underwired, however in roles which are more active, such as public order the percentage of officer wearing sports bra increases compared to other roles such as routine patrol.

\begin{tabular}{|l|c|c|c|c|c|}
\hline \multirow{2}{*}{ Primary role (n) } & \multicolumn{5}{c|}{ Type of bra (\% by primary role) } \\
\cline { 2 - 6 } & $\begin{array}{c}\text { No } \\
\text { bra }\end{array}$ & $\begin{array}{c}\text { Sports } \\
\text { bra }\end{array}$ & $\begin{array}{c}\text { Underwired } \\
\text { bra }\end{array}$ & $\begin{array}{c}\text { Padded / push up } \\
\text { bra }\end{array}$ & Other \\
\hline Routine Patrol (2008) & 0 & 17 & 71 & 9 & 3 \\
\hline $\begin{array}{l}\text { Specially trained firearms officer } \\
\text { (19) }\end{array}$ & 0 & 16 & 74 & 5 & 5 \\
\hline $\begin{array}{l}\text { Specially trained public disorder } \\
\text { officer (16) }\end{array}$ & 0 & 25 & 63 & 6 & 6 \\
\hline Traffic officer (66) & 2 & 23 & 65 & 6 & 5 \\
\hline Detective (311) & 0 & 14 & 74 & 9 & 4 \\
\hline $\begin{array}{l}\text { Custody / Offender management } \\
\text { (58) }\end{array}$ & 0 & 19 & 74 & 3 & 3 \\
\hline $\begin{array}{l}\text { Police community support officer } \\
\text { (14) }\end{array}$ & 0 & 20 & 73 & 0 & 7 \\
\hline Civilian staff (49) & 0 & 18 & 63 & 6 & 12 \\
\hline Other (81) & 1 & 17 & 70 & 9 & 2 \\
\hline Total across all roles (2622) & 0 & 17 & 71 & 8 & 3 \\
\hline
\end{tabular}

Table 4 Bra type worn by primary role within the police

The level of female officer perceived comfort when standing wearing body armour in relation to the type of bra worn is shown in Table 5. Overall, $67 \%$ of female officers found the wearing of body armour either uncomfortable or very uncomfortable regardless of bra type. The most comfortable bra identified was the padded/push up bra.

\begin{tabular}{|l|c|c|c|c|}
\hline & $\begin{array}{l}\text { Very } \\
\text { Comfortable }\end{array}$ & Comfortable & Uncomfortable & $\begin{array}{l}\text { Very } \\
\text { uncomfortable }\end{array}$ \\
\hline Underwired (1849) & $1 \%$ & $31 \%$ & $53 \%$ & $14 \%$ \\
\hline Sports (445) & $1 \%$ & $25 \%$ & $56 \%$ & $18 \%$ \\
\hline Padded/push up (219) & $2 \%$ & $42 \%$ & $45 \%$ & $11 \%$ \\
\hline Other (87) & $0 \%$ & $38 \%$ & $52 \%$ & $10 \%$ \\
\hline None (12) & $8 \%$ & $17 \%$ & $67 \%$ & $8 \%$ \\
\hline
\end{tabular}

Table 5 Comfort when standing in body armour with normal bra type worn

The effect of different bra type whilst wearing body armour was considered in Table 6 for a range of normal activities a police officer may perform. Walking was the easiest task performed compared to running which was considered the most difficult. The use of a firearm or TASER was balanced between easy and difficult, although the lower response rate should be noted as a result of less officers will be involved in these duties. 


\begin{tabular}{|c|c|c|c|c|c|}
\hline Activity & Bra type (n) & Very Easy & Easy & Difficult & Very difficult \\
\hline \multirow{5}{*}{$\begin{array}{l}\text { Sitting } \\
\text { in a car }\end{array}$} & Underwire (1775) & $2 \%$ & $37 \%$ & $48 \%$ & $13 \%$ \\
\hline & Sports (424) & $1 \%$ & $34 \%$ & $49 \%$ & $15 \%$ \\
\hline & Padded/push up (212) & $3 \%$ & $41 \%$ & $46 \%$ & $11 \%$ \\
\hline & Other $(82)$ & $0 \%$ & $35 \%$ & $52 \%$ & $12 \%$ \\
\hline & No bra (8) & $0 \%$ & $25 \%$ & $50 \%$ & $25 \%$ \\
\hline \multirow{5}{*}{$\begin{array}{c}\text { Driving } \\
\text { a car }\end{array}$} & Underwire (1754) & $1 \%$ & $25 \%$ & $52 \%$ & $20 \%$ \\
\hline & Sports (420) & $1 \%$ & $23 \%$ & $51 \%$ & $23 \%$ \\
\hline & Padded/push up (212) & $2 \%$ & $30 \%$ & $52 \%$ & $15 \%$ \\
\hline & Other (80) & $0 \%$ & $33 \%$ & $46 \%$ & $18 \%$ \\
\hline & No bra (7) & $0 \%$ & $0 \%$ & $75 \%$ & $13 \%$ \\
\hline \multirow{5}{*}{ Walking } & Underwire (1764) & $3 \%$ & $71 \%$ & $23 \%$ & $3 \%$ \\
\hline & Sports (423) & $3 \%$ & $72 \%$ & $22 \%$ & $3 \%$ \\
\hline & Padded/push up (211) & $4 \%$ & $73 \%$ & $21 \%$ & $2 \%$ \\
\hline & Other (81) & $2 \%$ & $72 \%$ & $25 \%$ & $1 \%$ \\
\hline & No bra (7) & $14 \%$ & $71 \%$ & $14 \%$ & $0 \%$ \\
\hline \multirow{5}{*}{ Running } & Underwire (1776) & $1 \%$ & $8 \%$ & $45 \%$ & $47 \%$ \\
\hline & Sports (425) & $0 \%$ & $6 \%$ & $44 \%$ & $50 \%$ \\
\hline & Padded/push up (210) & $0 \%$ & $7 \%$ & $48 \%$ & $44 \%$ \\
\hline & Other (82) & $0 \%$ & $11 \%$ & $42 \%$ & $46 \%$ \\
\hline & No bra (8) & $0 \%$ & $0 \%$ & $50 \%$ & $50 \%$ \\
\hline \multirow{5}{*}{$\begin{array}{c}\text { Self } \\
\text { defence }\end{array}$} & Underwire (1714) & $1 \%$ & $22 \%$ & $57 \%$ & $18 \%$ \\
\hline & Sports (408) & $0 \%$ & $21 \%$ & $57 \%$ & $20 \%$ \\
\hline & Padded/push up (202) & $1 \%$ & $29 \%$ & $53 \%$ & $15 \%$ \\
\hline & Other (79) & $0 \%$ & $27 \%$ & $47 \%$ & $22 \%$ \\
\hline & No bra (8) & $0 \%$ & $25 \%$ & $63 \%$ & $13 \%$ \\
\hline \multirow{5}{*}{$\begin{array}{l}\text { Using a } \\
\text { firearm } \\
\text { / TASER }\end{array}$} & Underwire (191) & $3 \%$ & $45 \%$ & $36 \%$ & $16 \%$ \\
\hline & Sports (62) & $5 \%$ & $47 \%$ & $34 \%$ & $15 \%$ \\
\hline & Padded/push up (23) & 0 & $57 \%$ & $39 \%$ & $4 \%$ \\
\hline & Other (6) & 0 & $50 \%$ & $33 \%$ & $17 \%$ \\
\hline & No bra (0) & 0 & 0 & 0 & 0 \\
\hline
\end{tabular}

Table 6 Ability to performing defined actions when wearing body armour and normal bra type worn

The areas on the torso (Figure 1, Table 1) that were identified as either rubbed and / or caused discomfort are compared by type of bra worn in Table 7.

The predominate regions identified by most respondents as the areas of greatest discomfort and / or rubbing were the left and right anterior mammary regions. This was except for the respondents who normally wore a padded / push up bra who had a lower percentage response in these areas. 


\begin{tabular}{|c|c|c|c|c|c|c|}
\hline \multirow[b]{2}{*}{ Zone } & \multicolumn{5}{|c|}{ Bra type (n) } & \multirow{2}{*}{$\begin{array}{l}\text { Overal } \\
\text { (9809) }\end{array}$} \\
\hline & $\begin{array}{c}\text { Underwired } \\
(6870)\end{array}$ & $\begin{array}{l}\text { Sports } \\
(1784)\end{array}$ & $\begin{array}{c}\text { Padded/push } \\
\text { up (810) }\end{array}$ & $\begin{array}{l}\text { Other } \\
(306)\end{array}$ & $\begin{array}{l}\text { None } \\
\text { (39) }\end{array}$ & \\
\hline $\begin{array}{c}\text { Right lateral } \\
\text { mammary region }\end{array}$ & $9 \%$ & $10 \%$ & $7 \%$ & $7 \%$ & $5 \%$ & $9 \%$ \\
\hline $\begin{array}{l}\text { Right anterior } \\
\text { mammary region }\end{array}$ & $11 \%$ & $12 \%$ & $9 \%$ & $14 \%$ & $13 \%$ & $11 \%$ \\
\hline $\begin{array}{c}\text { Left anterior } \\
\text { mammary region }\end{array}$ & $12 \%$ & $12 \%$ & $9 \%$ & $13 \%$ & $10 \%$ & $12 \%$ \\
\hline $\begin{array}{c}\text { Left lateral } \\
\text { mammary region }\end{array}$ & $10 \%$ & $10 \%$ & $7 \%$ & $9 \%$ & $8 \%$ & $10 \%$ \\
\hline $\begin{array}{l}\text { Posterior thoracic } \\
\text { region }\end{array}$ & $5 \%$ & $5 \%$ & $5 \%$ & $5 \%$ & $8 \%$ & $5 \%$ \\
\hline Right loin / flank & $4 \%$ & $4 \%$ & $5 \%$ & $4 \%$ & $0 \%$ & $4 \%$ \\
\hline Abdominal region & $6 \%$ & $6 \%$ & $8 \%$ & $9 \%$ & $13 \%$ & $6 \%$ \\
\hline Left loin / flank & $3 \%$ & $3 \%$ & $5 \%$ & $3 \%$ & $5 \%$ & $4 \%$ \\
\hline $\begin{array}{l}\text { Posterior lumbar- } \\
\text { sacral region }\end{array}$ & $8 \%$ & $8 \%$ & $9 \%$ & $8 \%$ & $8 \%$ & $8 \%$ \\
\hline $\begin{array}{l}\text { Right shoulder } \\
\text { region (deltoid) }\end{array}$ & $3 \%$ & $3 \%$ & $3 \%$ & $3 \%$ & $0 \%$ & $3 \%$ \\
\hline $\begin{array}{c}\text { Left anterior } \\
\text { shoulder region }\end{array}$ & $7 \%$ & $6 \%$ & $9 \%$ & $6 \%$ & $8 \%$ & $7 \%$ \\
\hline $\begin{array}{l}\text { Right anterior } \\
\text { shoulder region }\end{array}$ & $6 \%$ & $6 \%$ & $8 \%$ & $6 \%$ & $8 \%$ & $6 \%$ \\
\hline $\begin{array}{l}\text { Left shoulder region } \\
\text { (deltoid) }\end{array}$ & $3 \%$ & $3 \%$ & $3 \%$ & $3 \%$ & $0 \%$ & $3 \%$ \\
\hline $\begin{array}{l}\text { Right posterior } \\
\text { shoulder region }\end{array}$ & $6 \%$ & $6 \%$ & $7 \%$ & $5 \%$ & $8 \%$ & $6 \%$ \\
\hline $\begin{array}{l}\text { Left posterior } \\
\text { shoulder region }\end{array}$ & $6 \%$ & $6 \%$ & $6 \%$ & $5 \%$ & $8 \%$ & $6 \%$ \\
\hline
\end{tabular}

Table 7 Areas of rubbing / discomfort identified as percentage of respondent for each bra type worn

The areas identified by the respondents that were uncomfortable and / or rubbed were compared to the 10 most common bra sizes are shown in Table 8. The predominate regions identified as the areas of greatest discomfort and / or rubbing were the left and right anterior mammary regions. There is a tendency that as bra size increases the percentage of responses in these two areas increases. 


\begin{tabular}{|c|c|c|c|c|c|c|c|c|c|c|}
\hline & $\begin{array}{l}32 \mathrm{C} \\
(258)\end{array}$ & $\begin{array}{l}34 \mathrm{~B} \\
(780)\end{array}$ & $\begin{array}{c}34 \mathrm{C} \\
(728)\end{array}$ & $\begin{array}{l}34 D \\
(544)\end{array}$ & $\begin{array}{l}\text { 34DD } \\
(580)\end{array}$ & $\begin{array}{l}36 \mathrm{~B} \\
(493)\end{array}$ & $\begin{array}{l}36 C \\
(781)\end{array}$ & $\begin{array}{l}36 \mathrm{D} \\
(506)\end{array}$ & $\begin{array}{l}\text { 36DD } \\
(457)\end{array}$ & $\begin{array}{l}38 \mathrm{C} \\
(269)\end{array}$ \\
\hline $\begin{array}{l}\text { Right lateral mammary } \\
\text { region ( } 2 \text { ) }\end{array}$ & $6 \%$ & $8 \%$ & $9 \%$ & $8 \%$ & $12 \%$ & $8 \%$ & $8 \%$ & $10 \%$ & $9 \%$ & $8 \%$ \\
\hline $\begin{array}{l}\text { Right anterior mammary } \\
\text { region (6) }\end{array}$ & $11 \%$ & $8 \%$ & $10 \%$ & $11 \%$ & $12 \%$ & $11 \%$ & $10 \%$ & $13 \%$ & $13 \%$ & $10 \%$ \\
\hline $\begin{array}{l}\text { Left anterior mammary } \\
\text { region ( } 7)\end{array}$ & $10 \%$ & $10 \%$ & $11 \%$ & $12 \%$ & $12 \%$ & $11 \%$ & $12 \%$ & $15 \%$ & $12 \%$ & $11 \%$ \\
\hline $\begin{array}{l}\text { Left lateral mammary region } \\
\qquad(10)\end{array}$ & $7 \%$ & $8 \%$ & $9 \%$ & $9 \%$ & $12 \%$ & $8 \%$ & $9 \%$ & $11 \%$ & $9 \%$ & $9 \%$ \\
\hline $\begin{array}{l}\text { Posterior thoracic region } \\
\text { (15) }\end{array}$ & $7 \%$ & $5 \%$ & $5 \%$ & $5 \%$ & $5 \%$ & $7 \%$ & $4 \%$ & $6 \%$ & $4 \%$ & $4 \%$ \\
\hline Right loin / flank (3) & $5 \%$ & $4 \%$ & $5 \%$ & $5 \%$ & $3 \%$ & $3 \%$ & $5 \%$ & $4 \%$ & $5 \%$ & $3 \%$ \\
\hline Abdominal region (8) & $9 \%$ & $8 \%$ & $5 \%$ & $8 \%$ & $7 \%$ & $7 \%$ & $8 \%$ & $6 \%$ & $6 \%$ & $6 \%$ \\
\hline Left loin / flank (11) & $4 \%$ & $4 \%$ & $4 \%$ & $4 \%$ & $3 \%$ & $4 \%$ & $5 \%$ & $3 \%$ & $5 \%$ & $3 \%$ \\
\hline $\begin{array}{l}\text { Posterior lumbar-sacral } \\
\text { region (15) }\end{array}$ & $8 \%$ & $9 \%$ & $9 \%$ & $8 \%$ & $8 \%$ & $9 \%$ & $11 \%$ & $6 \%$ & $9 \%$ & $9 \%$ \\
\hline $\begin{array}{l}\text { Right shoulder region } \\
\text { (deltoid) (1) }\end{array}$ & $3 \%$ & $3 \%$ & $2 \%$ & $2 \%$ & $2 \%$ & $3 \%$ & $3 \%$ & $3 \%$ & $4 \%$ & $3 \%$ \\
\hline $\begin{array}{l}\text { Left anterior shoulder region } \\
\text { (5) }\end{array}$ & $7 \%$ & $7 \%$ & $7 \%$ & $5 \%$ & $6 \%$ & $7 \%$ & $6 \%$ & $6 \%$ & $5 \%$ & $10 \%$ \\
\hline $\begin{array}{l}\text { Right anterior shoulder } \\
\text { region (4) }\end{array}$ & $8 \%$ & $8 \%$ & $8 \%$ & $6 \%$ & $6 \%$ & $6 \%$ & $6 \%$ & $6 \%$ & $5 \%$ & $9 \%$ \\
\hline $\begin{array}{l}\text { Left shoulder region } \\
\text { (deltoid) (9) }\end{array}$ & $3 \%$ & $3 \%$ & $2 \%$ & $3 \%$ & $1 \%$ & $4 \%$ & $2 \%$ & $3 \%$ & $3 \%$ & $3 \%$ \\
\hline $\begin{array}{l}\text { Left posterior shoulder } \\
\text { region (12) }\end{array}$ & $6 \%$ & $8 \%$ & $7 \%$ & $6 \%$ & $5 \%$ & $6 \%$ & $6 \%$ & $4 \%$ & $7 \%$ & $7 \%$ \\
\hline $\begin{array}{l}\text { Right posterior shoulder } \\
\text { region (13) }\end{array}$ & $6 \%$ & $8 \%$ & $6 \%$ & $6 \%$ & $5 \%$ & $5 \%$ & $5 \%$ & $5 \%$ & $6 \%$ & $6 \%$ \\
\hline
\end{tabular}

Table 8 Areas of rubbing / discomfort identified as percentage of respondent for each bra type for 10 most common bra sizes

\subsection{Discussion}

The purpose of this study was to understand the distribution of bra size and bra type within the female police population in England and Wales and the effect this had on comfort of wearing body armour. In addition, data gathered on comfort and physical activity enabled the development of an understanding of issues for female police officers to be developed.

The key findings from this study were 
- the most common bra type currently worn by female polices officers in the England and Wales is underwired (71\%) followed by sports bras (17\%),

- the most common officer declared UK bra size is $34 \mathrm{~B}(9 \%)$ with a range of $23 \mathrm{~B}$ to $80 \mathrm{C}$ and

- the most reported areas of rubbing and / or discomfort were around the anterior mammary regions and posterior lumbar-sacral region.

The sample size of the survey (2633 respondents) enabled a comprehensive picture to be formed to support the key findings in this study. The largest percentage of respondents were routine patrol officers $(76 \%)$, with smaller numbers from more specialised roles. This bias was expected due to the primary role of most police officers being routine patrol. However, all these officers would be wearing their issued body armour for much of their shift.

The bra size data was the size declared by the respondent at the time they completed the survey. It should be noted that it is possible that officers may not be wearing the correct sized bra or that between bra manufacturers there may be a discrepancy in sizing. This survey does demonstrate that within the respondents there was four main clusters of bra size declared. By understanding the spread of bra sizes, it may support the development of improved size ranges of body armour for female wearers.

The primary type of bra across all roles that an officer chooses to wear under their body armour was underwired (63 to 74\%), although the exact type and style was not ascertained. In some of the more physically demanding roles, including public order officers, more officers declared that they used sports bras (25\%) compared to routine patrol $(17 \%)$, although the majority still specified underwired (63\%). This may be due to the more physical nature of the duties and training conducted by public order officers. The data did show one occurrence that was unexpected, traffic officers, which may be perceived as a less physical role potentially, had a higher than expected percentage of respondents wearing sports bras (23\%) compared to the average across all roles (17\%). The wearing of seatbelts, manoeuvring in and out of vehicles and the requirement to go from sitting to running may explain this.

It is expected that a certain amount of the rubbing and / or discomfort for all users of armour will be directly related to the wearing of body armour and the burden that places on the person. For female officers this may be exaggerated or in different areas due to the physiological differences (e.g. breasts, waist size, shoulder width). 
The type of bra made little difference to the areas identified as either rubbing and / or discomfort for the respondents, except for the padded bra which showed less rubbing and / or discomfort on the anterior mammary regions, than all other types of bras. When size of the bra is considered, the main areas identified as rubbing and / or discomfort were the same as for bra type, however as the bra sized increase there was an increase in respondents identifying the breast as areas of discomfort or rubbing. This could be related to lack of support for larger breasts or poor fitting of the armour.

The data collected concerning comfort when standing and activities when wearing body armour indicates that the wearing of body armour causes a level of discomfort and restriction in capability to perform actions. Some of this may be due to the body armour itself and the restriction that it places on movement as identified from the literature. However, the most difficult task identified for all bra types was running, followed closely by self-defence. These are the two most physical activities surveyed and may be an indication that bra type and support may be critical in comfort when wearing body armour.

Some of the factors that affect the comfort of the armour may be due to the design, fit and shape of armour itself, especially where discomfort occurs at the side of the breast. This paper has not considered the effect of carriage of equipment on comfort and ease of activity. The style and correct sizing of the bra has also not been considered, as although generic descriptors were used for the bra type, details of the bra, materials used in the bra and age of the bra were not considered.

The survey has provided a data set from which it is possible to hypothesise that comfort of body armour relates to the interaction between bust size, bra type and precise shape of the contours of the female body compared to the design of body armour, although further work building on this survey is needed to develop a greater understanding.

\subsection{Conclusions}

This study has developed a comprehensive data set for UK female police officers for size range and type of bra worn, both of which will influence the form and shape of the breast under body armour. The two most commonly worn bra types were underwired (71\%) and sports bra (17\%) with nine percent of respondents wearing size 34B bra. The data does not conclude that one bra type is better than another when comfort wearing body armour is considered, although potentially padding can improve comfort in certain circumstances. 
By understanding the effects body armour has on female officers it may be possible to focus design efforts into improving the comfort, fit and protection afforded in an area that has had less research compared to armour for male users since body armour was first developed.

\section{Acknowledgements}

Centre for Defence Engineering, Cranfield University, Defence Academy of the United Kingdom, Shrivenham, UK for funding the research

The Police Federation of England and Wales for distributing the survey to their members and supporting this research.

Surg Lt Cdr (RN) T Stevenson for medical definitions.

\section{References}

Abtew, M.A., Bruniaux, P., Boussu, F., 2017. Development of adaptive bust for female soft body armour using three dimensional (3D) warp interlock fabrics: Three dimensional (3D) design process. IOP Conf. Ser. Mater. Sci. Eng. 254. https://doi.org/10.1088/1757-899X/254/5/052001

Abtew, M.A., Bruniaux, P., Boussu, F., Loghin, C., Cristian, I., Chen, Y., 2018. Development of comfortable and well-fitted bra pattern for customized female soft body armor through 3D design process of adaptive bust on virtual mannequin. Comput. Ind. 100, 7-20. https://doi.org/10.1016/j.compind.2018.04.004

Bir, C., Wilhelm, M., 2004. FEMALE BODY ARMOR ASSESSMENT: CURRENT METHODS AND FUTURE TECHNIQUES, in: PASS.

Boussu, F., Bruniaux, P., 2012. Customization of a lightweight bullet-proof vest for the female form, in: Advances in Military Textiles and Personal Equipment. Elsevier, pp. 167-195. https://doi.org/10.1533/9780857095572.2.167

Brown, N., White, J., Brasher, A., Scurr, J., 2014. An investigation into breast support and sports bra use in female runners of the 2012 London Marathon. J. Sports Sci. 32, 801-809. https://doi.org/10.1080/02640414.2013.844348

Cannon, L., 2001. Behind armour blunt trauma--an emerging problem. J. R. Army Med. Corps 147, 87-96. https://doi.org/10.1136/jramc-147-01-09

Carr, D.J., Horsfall, I., Malbon, C., 2013. Is behind armour blunt trauma a real threat to users of body armour? A systematic review. J. R. Army Med. Corps 1-4. https://doi.org/10.1136/jramc-2013000161

Carr, D.J., Wilson, C.A., Laing, R.M., 2012. Anthropometric methods for the successful design of military clothing and equipment, in: Advances in Military Textiles and Personal Equipment. Elsevier, pp. 49-63. https://doi.org/10.1533/9780857095572.1.49

Cichocka, A., Bruniaux, P., Frydrych, I., 2014. 3D Garment Modelling - Creation of a virtual mannequin of the human body. Fibres Text. East. Eur. 22, 123-131.

Dempsey, P.C., Handcock, P.J., Rehrer, N.J., 2013. Impact of police body armour and equipment on mobility. Appl. Ergon. 44, 957-961. https://doi.org/10.1016/j.apergo.2013.02.011

Filtness, A.J., Mitsopoulos-Rubens, E., Rudin-Brown, C.M., 2014. Police officer in-vehicle discomfort: Appointments carriage method and vehicle seat features. Appl. Ergon. 45, 1247-1256. https://doi.org/10.1016/j.apergo.2014.03.002

Hargreaves, J., Husband, H., Lineham, C., 2017. Police workforce, England and Wales, 31 March 2017, Governemnet Publications.

International Organization for Standarization (ISO), 2017. Size designation of clothes- Part 1: Anthropometric definitions for body measurement.

Jennings, R.M., Malbon, C., Brock, F., Harrisson, S., Carr, D.J., 2018. A preliminary study into injuries due to non-perforating ballistic impacts into soft body armour over the spine. Injury. https://doi.org/10.1016/j.injury.2018.05.015 
Jennings, Rosalind M, Malbon, C., Brock, F., Harrisson, S.E., Carr, D.J., 2018. Preliminary study into the skeletal injuries sustained to the spine from posterior non-perforating ballistic impacts into body armour. J. R. Army Med. Corps 164, 186-190. https://doi.org/10.1136/jramc-2017-000893

Lewinski, W.J., Dysterheft, J.L., Dicks, N.D., Pettitt, R.W., 2015. The influence of officer equipment and protection on short sprinting performance. Appl. Ergon. 47, 65-71. https://doi.org/10.1016/j.apergo.2014.08.017

Lewis, E.A., Breeze, J., Malbon, C., Carr, D.J., 2017. Personal Armour Used by UK Armed Forces and UK Police Forces, in: Breeze, J (Ed.), Ballistic Trauma. Springer International Publishing, Cham, pp. 47-62. https://doi.org/10.1007/978-3-319-61364-2_6

Mahbub, R., Wang, L., Arnold, L., 2014. International Journal of Fashion Design, Technology and Education Design of knitted three-dimensional seamless female body armour vests Design of knitted three-dimensional seamless female body armour vests. Int. J. Fash. Des. Technol. Educ. 7, 198-207. https://doi.org/10.1080/17543266.2014.956152

Milligan, A., Mills, C., Scurr, J., 2014. The effect of breast support on upper body muscle activity during $5 \mathrm{~km}$ treadmill running. Hum. Mov. Sci. 38, 74-83. https://doi.org/10.1016/j.humov.2014.06.001

Mithchell, K.B., Garlie, T., Guerra, R., 2010. Antropometric and Human Factors Evaluation of a body armour vest with females: A report of methodology, in: PASS.

Payne, T., O’Rourke, S., Malbon, C., 2017. Home Office Body Armour Standard ( 2017 ).

Pechter, E.A., 1998. A New Method for Determining Bra Size and Predicting Postaugmentation Breast Size. Plast. Reconstr. Surg. 102, 1259-1265. https://doi.org/10.1097/00006534199809040-00056

Ramstrand, N., Zügner, R., Larsen, L.B., Tranberg, R., 2016. Evaluation of load carriage systems used by active duty police officers: Relative effects on walking patterns and perceived comfort. Appl. Ergon. 53, 36-43. https://doi.org/10.1016/j.apergo.2015.08.007

Salusso-Deonier, C.J., Delong, M., Martin, F., Krohn, K., 1985. Multivariate method of classifying body form variation for sizing women's apparel. Cloth. Text. Res. J. 4, 38-45.

Tilsley, L., Carr, D.J., Lankester, C., Malbon, C., 2018. Do air-gaps behind soft body armour affect protection? J R Army Med Corps 164, 15-18. https://doi.org/10.1136/jramc-2016-000759

White, J., Mills, C., Ball, N., Scurr, J., 2015. The effect of breast support and breast pain on upperextremity kinematics during running: implications for females with large breasts. J. Sports Sci. 33, 2043-50. https://doi.org/10.1080/02640414.2015.1026378

Zheng, R., Yu, W., Fan, J., 2006. Breast measurement and sizing, in: Innovation and Technology of Women's Intimate Apparel. Elsevier, pp. 28-58. https://doi.org/10.1016/B978-1-84569-0465.50002-1 
Annex 1 - Copy of survey distributed to female police officers

Female police officers

Q9 I confirm that I have been informed about the aim and objectives of this research project and agree to give my inputs. I understand that all information that I provide will be treated with the strictest confidence and my name will not be used in any report, publication or presentation. I understand that the information I provide will be used by Cranfield University for the purpose of research only. The data will be stored on a secure network accessed only by authorised users in accordance with the Data Protection Act (1998). I I understand that the results of the research may be published in scientific journals, and an anonymised version of the data may be published in support of these results. I understand that I am not required to answer a question if I prefer not to provide a response. I understand that I am free to withdraw from this survey at any stage.

O By ticking this box, I confirm that I am happy to particpate (1)

Q1 What is your primary role?

O Routine Patrol (1)

O Firearms (2)

O Public Order (3)

O Dog Handler (4)

O Mounted Branch (5)

O Traffic (6)

Other (please specify) (7)

Q2 How many years have you been wearing body armour?

$0<2(1)$

○ 2 to 5 (2)

O 6 to $10(3)$

○ 11 to $15(4)$

O 16 to $20(5)$

O >20 (6)

Q3 What size bra do you normally wear?

Q4 What type of bra do you normally wear under your body armour

O No bra (1)

O Sports bra (2)

O Underwired bra (3)

O Padded/push up bra (5)

O Other (please specify) (7)

Q5 When standing wearing your body armour, how comfortable is it?

O Very Comfortable (1)

O Comfortable (2)

O Uncomfortable (3)

O Very Uncomfortable (4) 
Q6 On the images below, please indicate any areas that are uncomfortable or rub when wearing your body armour. (click on image with mouse, maximum of 10 points)
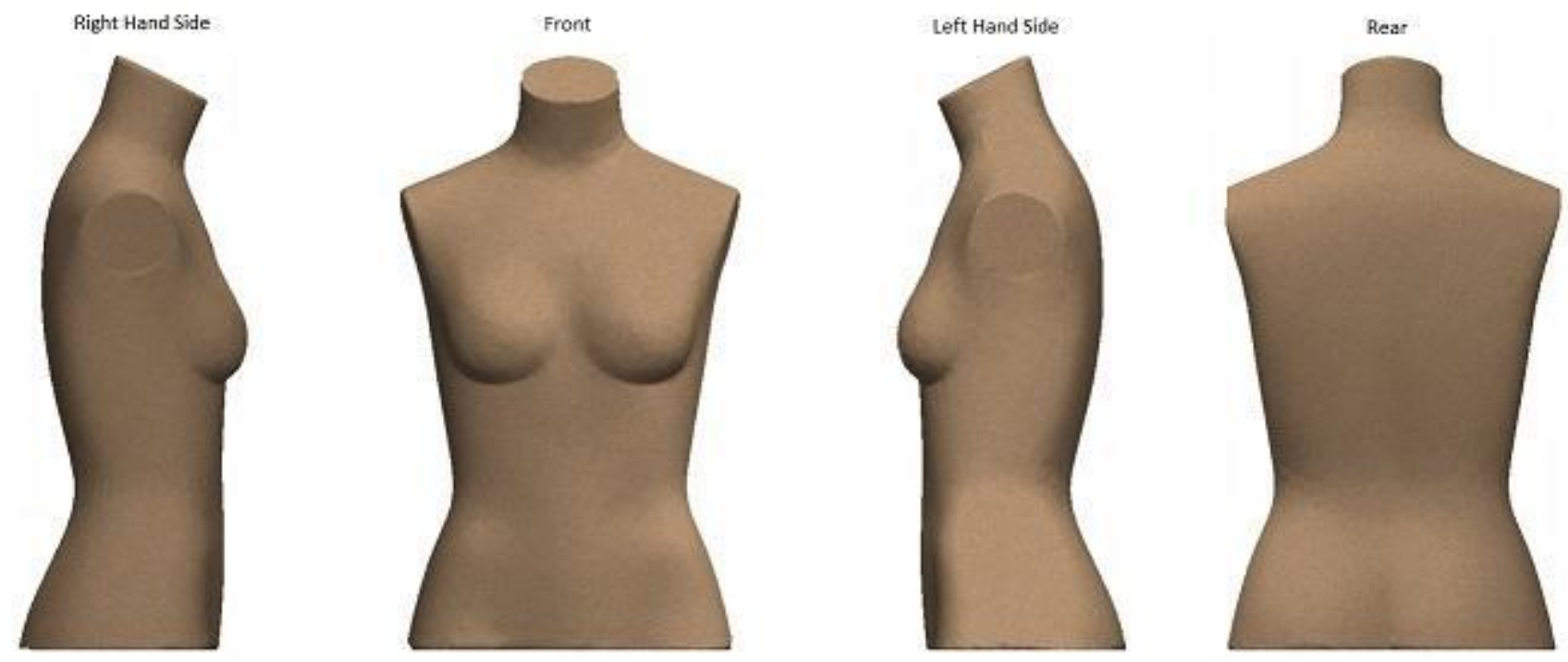

Q7 Whilst wearing your body armour, please rate the following actions (if applicable)

\begin{tabular}{|c|c|c|c|c|c|}
\hline & Very Easy (1) & Easy (2) & Difficult (3) & $\begin{array}{c}\text { Very Difficult } \\
\text { (4) }\end{array}$ & $\begin{array}{l}\text { Not applicable } \\
\text { (5) }\end{array}$ \\
\hline $\begin{array}{l}\text { Sitting in a car } \\
\text { (passenger) } \\
\text { (1) }\end{array}$ & $\mathrm{O}$ & O & $O$ & O & O \\
\hline $\begin{array}{l}\text { Driving a car } \\
\text { (2) }\end{array}$ & $\mathrm{O}$ & 0 & 0 & 0 & O \\
\hline Walking (3) & O & O & O & O & O \\
\hline Running (4) & O & O & O & O & O \\
\hline $\begin{array}{l}\text { Self defence } \\
\text { techniques (5) }\end{array}$ & 0 & O & 0 & O & O \\
\hline $\begin{array}{c}\text { Using a } \\
\text { pistol/TASER } \\
\text { (6) }\end{array}$ & O & 0 & 0 & 0 & O \\
\hline $\begin{array}{l}\text { Using a } \\
\text { carbide (7) }\end{array}$ & $\mathrm{O}$ & O & 0 & O & O \\
\hline $\begin{array}{l}\text { Riding (horse) } \\
\text { (8) }\end{array}$ & 0 & 0 & 0 & 0 & 0 \\
\hline $\begin{array}{l}\text { Riding (pedal } \\
\text { cycle) (9) }\end{array}$ & O & 0 & O & O & O \\
\hline $\begin{array}{c}\text { Riding } \\
\text { (motorbike) } \\
(10)\end{array}$ & O & O & O & O & O \\
\hline
\end{tabular}


Q8 Please indicate which items of equipment you routinely carry on either your body armour, or on a belt

\begin{tabular}{|c|c|c|c|}
\hline & Body Armour (1) & Belt (2) & Not applicable (3) \\
\hline Handcuffs (1) & 0 & 0 & 0 \\
Irritant spray (2) & 0 & 0 & 0 \\
TASER (3) & 0 & 0 & 0 \\
Police radio (4) & 0 & 0 & 0 \\
Police mobile phone & 0 & 0 & 0 \\
$(5)$ & 0 & 0 & 0 \\
Personal mobile & 0 & 0 \\
phone (6) & 0 & 0 & 0 \\
Notebook (7) & 0 & 0 & 0 \\
Baton (8) & 0 & 0 & 0 \\
\hline $\begin{array}{c}\text { Body worn video (9) } \\
\text { Other (please specify) }\end{array}$ \\
(10)
\end{tabular}

